ISSN : $2302-1590$

E-ISSN: $2460-190 \mathrm{X}$

ECONOMICA

Journal of Economic and Economic Education Vol.1 No.2 (223-230)

\title{
PENERAPAN STANDAR AKUNTANSI KEUANGAN ENTITAS TANPA AKUNTABILITAS PUBLIK (SAK ETAP) (Studi Kasus Pada CV. Citra Pandion Bernas di Kabupaten Solok)
}

\author{
Floren Violetfin Leries ${ }^{1}$, Fefri Indra Arza ${ }^{2}$, Citra Ramayani ${ }^{3}$ \\ Mahasiswa Program Studi Pendidikan Ekonomi ${ }^{1}$ Dosen Program Studi Akutansi Universitas Negeri \\ Padang $^{2}$ Dosen Program Studi Pendidikan Ekonomi STKIP- PGRI Sumbar ${ }^{3}$ \\ Jl. Gunung Pangilun No.1, Padang Sumatera Barat. \\ Email: FlorenVioletfinLeries@yahoo.com
}

submited: 2013.01.21 reviewed: 2013.02.17 accepted: 2013.04.29

http://dx.doi.org/10.22202/economica.2013.v1.i2.123

\begin{abstract}
This research background overshadowed by presentation of CV Citra Pandion Bernas financial statement. Which is not required by ZAK of ETAP consist of balance, balance report, statement of changes in ekuitas, cash flow statement, and note of financial statement. While presented by financial statement is CV Citra Pandion Bernas only consisting of, profit report, capital statement and balance. Result of research indicate that CV.CITRA Pandion Bernas have applied its financial statement pursuant to ZAK of ETAP but not yet fully, still many element which not yet according to ZAK of ETAP, that is earnings which do not be dissociated pursuant to between operating income and earnings outside effort which is obtained. All purchasing of supply grouped in burden account at balance report, ought to supply when only which have used taken as burden that is equal to $70 \%$ from supply value. natural constraint by CV.CITRA Pandion Bernas in applying CV.CITRA Pandion Bernas among others, existence of mistake of conducted by calculation is CV.CITRA Pandion Bernas. There no division of clear duty between area because owner at the same time become organizer of[is effort. Owner also have other effort to be developed so that do not too focus at one area of is effort. Lack of human resource owning ability in compiling financial statement because do not in supporting with background education of accountancy.
\end{abstract}

Abstrak
Latar belakang penelitian ini dibayangi oleh penyajian laporan keuangan CV Citra Pandion Bernas. Yang tidak diperlukan oleh ZAK dari ETAP terdiri dari keseimbangan, laporan neraca, laporan perubahan TOTAL, laporan arus kas, dan catatan atas laporan keuangan. Sementara disajikan oleh laporan keuangan adalah CV Citra Pandion Bernas hanya terdiri dari, laporan laba, laporan modal dan keseimbangan. Hasil penelitian menunjukkan bahwa CV.CITRA Pandion Bernas telah diterapkan laporan keuangan sesuai dengan ZAK dari ETAP tetapi belum sepenuhnya, masih banyak elemen yang belum sesuai ZAK dari ETAP, yaitu penghasilan yang tidak terpisahkan sesuai antara laba operasi dan pendapatan di luar usaha yang diperoleh. Semua pembelian pasokan dikelompokkan dalam akun beban di laporan neraca, harus menyediakan ketika hanya yang telah digunakan diambil sebagai beban yaitu sebesar $70 \%$ dari nilai pasokan. kendala alam oleh CV.CITRA Pandion Bernas dalam menerapkan CV.CITRA Pandion Bernas antara lain, adanya kesalahan yang dilakukan oleh perhitungan CV.CITRA Pandion Bernas. Tidak ada pembagian tugas yang jelas antara daerah karena pemilik pada saat yang sama menjadi penyelenggara [usaha. Pemilik juga memiliki usaha lain untuk dikembangkan sehingga tidak terlalu fokus pada satu bidang usaha. Kurangnya sumber daya manusia yang memiliki kemampuan dalam menyusun laporan keuangan karena tidak dalam mendukung dengan latar belakang pendidikan akuntansi.

Keyword: ZAK of ETAP, Financial Statement.

C2013 Prodi Pendidikan Ekonomi STKIP PGRI, Padang 


\section{PENDAHULUAN}

Pada dasarnya tujuan didirikan sebuah perusahaan adalah untuk memperoleh profit yang maksimal sehingga dapat mempertahankan dan menjaga kelangsungan perusahaan itu sendiri. Oleh karena itu semua kegiatan yang dilakukan oleh perusahaan selalu diarahkan dalam pencapaian kestabilan kelangsungan hidup dan perkembangan perusahaan. Perekonomian yang semakin berkembang dengan ditandainya dengan pendirian perusahaan yang semakin menjamur, akan menimbulkan persaingan antar perusahaan yang semakin ketat, sehingga membuat bidang keuangan harus mendapat perhatian yang lebih. Dalam bidang keuangan suatu media penting dibutuhkan dalam proses pengambilan keputusan ekonomis. Media tersebut adalah berupa laporan keuangan. Laporan keuangan merupakan media informasi yang dapat membantu para pengusaha dalam mendeskripsikan keadaan perusahaannya. Namun informasi yang terdapat pada laporan keuangan belum bisa digunakan seutuhnya untuk menilai kinerja dari suatu perusahaan, masih dibutuhkan analisis yang tepat terhadap laporan keuangan tersebut.

Ikatan Akuntan Indonesia (IAI) pada tanggal 17 Juli 2009 yang lalu, telah menerbitkan Standar Akuntansi Keuangan untuk Entitas Tanpa Akuntabilitas Publik (SAK-ETAP). IAI menerbitkan standar ini adalah untuk mempermudah perusahaan kecil menengah yang jumlahnya hampir 90\% dari total perusahaan di Indonesia dalam menyusun laporan keuangan mereka. Dengan adanya SAK ETAP ini perusahaan kecil menengah tidak perlu menyusun laporan keuangan mereka berdasarkan SAK yang berlaku umum.

Pihak-pihak yang membutuhkan laporan keuangan perlu memahami apa arti dari angka yang ada dalam laporan keuangan dan bagaimana menganalisis serta menafsirkan data keuangan dengan cara yang logis dan sistematis. Namun dalam praktiknya terdapat beberapa perusahaan yang belum melakukan pembukuan atau pencatatan keuangannya berdasarkan standar akuntansi keuangan. Hal tersebut timbul karena pemilik perusahaan berasumsi bahwa perusahaan mereka belum terlalu besar kegiatan operasinya. Padahal laporan keuangan adalah hal yang paling essensial bagi pemilik perusahaan sebagai dasar untuk mengembangkan usaha mereka dalam hal pengambilan keputusan.

CV. Citra Pandion Bernas adalah termasuk salah satu perusahaan kecil menegah yang terdapat di Kabupaten Solok yang bergerak di bidang jasa. Produk jasa yang dijual oleh CV Citra Pandion Bernas ini adalah service dokumen, dan service computer. Dalam menyusun laporan keuangan CV Citra Pandion Bernas belum menyajikan laporan keuangan lengkap seperti yang disyaratkan dalam SAK ETAP yang terdiri atas neraca, laporan laba rugi, laporan perubahan ekuitas, laporan arus kas, dan catatan atas atas laporan keuangan. Laporan keuangan yang dibuat oleh CV. Citra Pandion Bernas ini kurang mampu menyediakan informasi yang lengkap karena laporan keuangan yang disajikan CV Citra Pandion Bernas hanya terdiri dari laporan laba rugi, laporan perubahan modal dan neraca.

Penelitian yang penulis lakukan ini adalah penelitian kualitatif dengan metode studi kasus. Metode penelitian kualitatif adalah metode penelitian yang digunakan untuk meneliti kondisi objek alamiah, (lawannya adalah eksperimen) dimana peneliti merupakan instrument kunci, teknik pengumpulan data dilakukan secara triangulasi (gabungan), analisis data bersifat induktif, dan hasil penelitian kualitatif lebih menekankan makna daripada generalisasi (Afifuddin \& Saebani, 2012: 57-58). Studi kasus adalah suatu inkuiri empiris yang menyelidiki fenomena di dalam konteks kehidupan nyata bilamana batas-batas antara fenomena dan konteks tak tampak dengan 
tegas dan dimana multi sumber bukti dimanfaatkan (Robert K. Yin, 2002: 18).

Tempat penulis melakukan penelitian ini adalah pada CV. Citra Pandion Bernas jalan raya Solok-Padang kilometer satu Kelurahan Bawah Jao, Nagari Selayo Kecamatan Kubung Kabupaten Solok yang dimulai pada bulan Agustus 2013.

Jenis data dalam penelitian ini adalah data kuantitatif dan data kualitatif. Data kuantitatif yaitu data-data pendukung perhitungan tarif jasa yang ada pada CV. Citra Pandion Bernas Di Kabupaten Solok. Data kualitatif yaitu data-data berupa struktur organisasi, proses pencatatan keuangan, peralatan dan perlengkapan yang digunakan dan lainnya.

Sumber data dalam penelitian ini adalah data sekunder. Data sekunder yang penulis gunakan dalam penelitian ini berasal dari laporan keuangan CV Citra Pandion Bernas periode desember 2012.

Dalam penelitian ini penulis akan melaksanakan pengumpulan data dengan teknik dokumentasi, wawancara dan observasi. Dokumentasi merupakan catatan peritiwa yang sudah berlalu, dokumen bisa berbentuk tulisan, gambar, atau karyakarya monumental seseorang (Sugiono, 2012: 329). Wawancara adalah metode pengambilan data dengan cara menanyakan sesuatu kepada seseorang yang menjadi informan atau responden, caranya adalah dengan bercakap-cakap secara tatap muka, wawancara dapat dilakukan dengan menggunakan responden wawancara atau dengan tanya jawab secara langsung (Afifuddin \& Saebani, 2012: 131). Menurut Nawawi \& Martini dalam (Afifuddin \& Saebani, 2012: 134) observasi adalah pengamatan dan pencatatan secara sistematik terhadap unsur-unsur yang tampak dalam suatu gejala atau gejala-gejala dalam objek penelitian.

Dalam penelitian ini variabel yang akan penulis gunakan adalah:

\section{SAK ETAP}

Standar Akuntansi Keuangan Entitas Tanpa Akuntabilitas Publik (SAK
ETAP) ini dimaksudkan untuk digunakan oleh entitas tanpa akuntabilitas publik.

2. Laporan Keuangan

Laporan keuangan dalam operasional penelitian ini adalah laporan keuangan yang disajikan oleh CV.Citra Pandion Bernas tahun 2012.

Teknik analisis yang penulis gunakan pada penelitian ini adalah analisis deskriptif komparatif yaitu menggambarkan dan membandingkan laporan keuangan yang dibuat oleh CV. Citra Pandion Bernas Di Kabupaten Solok selama ini dengan laporan keuangan berdasarkan Standar Akuntansi Keuangan Entitas Tanpa Akuntabilitas Publik (SAK ETAP).

\section{PEMBAHASAN}

\section{Profil Perusahaan}

CV Citra Pandion Bernas berdiri sejak tahun 2003 beralamat di jalan raya Solok-Padang Km 1 Kelurahan Bawah Jao Nagari Selayo Kecamatan Kubung Kabupaten Solok. Pendapatan rata-rata yang diperoleh tiap bulannya berkisar $\mathrm{Rp}$ 16.000.0000 hingga Rp 17.000.000 dan memiliki asset sekitar Rp 200.000.000. CV Citra Pandion Bernas ini dikelola secara langsung oleh pemiliknya yaitu Bapak Harmenius, S.Si dan dibantu 3 orang karyawannya.

CV Citra Pandion Bernas
melakukan
pencatatan transaksi
pendapatan, pembelian perlengkapan, pembelian peralatan, pembayaran gaji karyawan, pembayaran sewa toko, pembayaran listrik, air telepon, pembayaran angsuran utang bank dan penyusutan peralatan serta transaksi lainnya yang terjadi setiap bulan berjalan hingga menghasilkan laporan keuangan yang terdiri atas laporan laba/rugi, laporan perubahan modal serta neraca. CV Citra Pandion Bernas ini bergerak dalam bidang jasa yaitu service dokumen dan service komputer.

Dalam Standar Akuntansi Keuangan Entitas Tanpa Akuntabilitas 
Publik (SAK ETAP) laporan keuangan yang lengkap terdiri atas: nerara, laporan laba rugi, laporan perubahan ekuitas, laporan arus kas dan catatan atas laporan keuangan. Sedangkan dalam laporan

Tabel 1. Laporan Laba/Rugi CV Citra Pandion Bernas

\section{Citra Pandion Bernas}

Laporan Laba/Rugi

Desember 2012

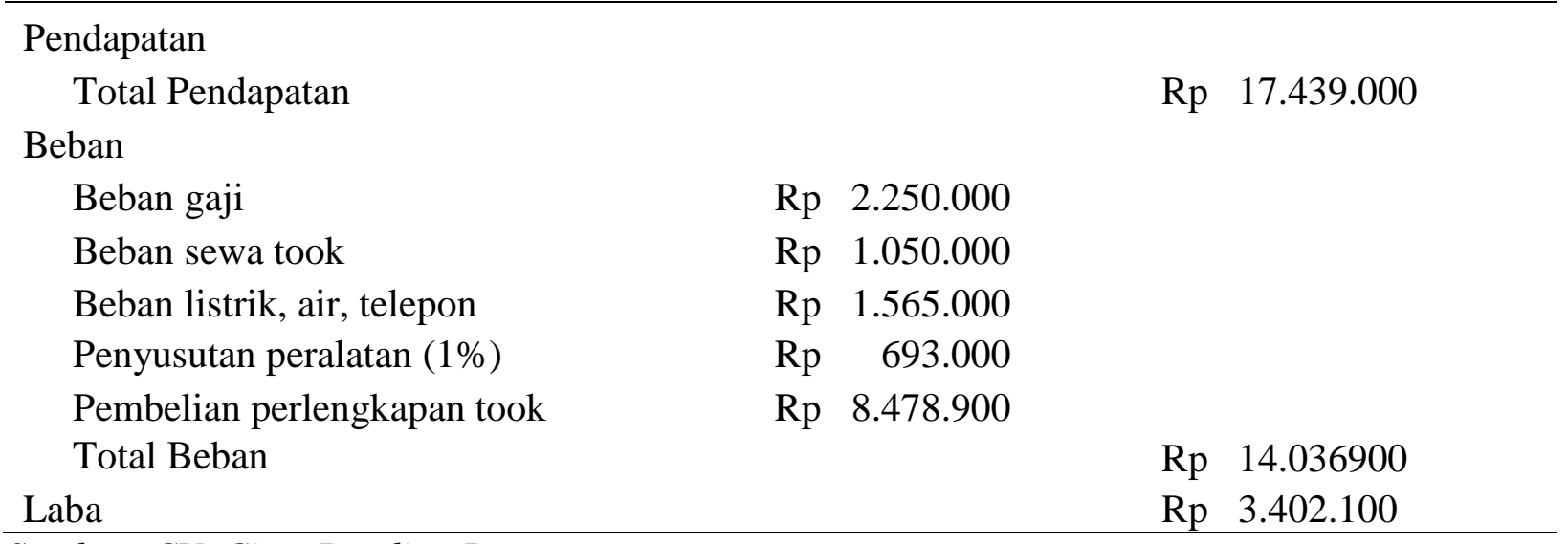

Sumber: CV. Citra Pandion Bernas

Tabel 2. Laporan Perubahan Modal CV Citra Pandion Bernas

CV Citra Pandion Bernas

Laporan Perubahan Modal

Desember 2012

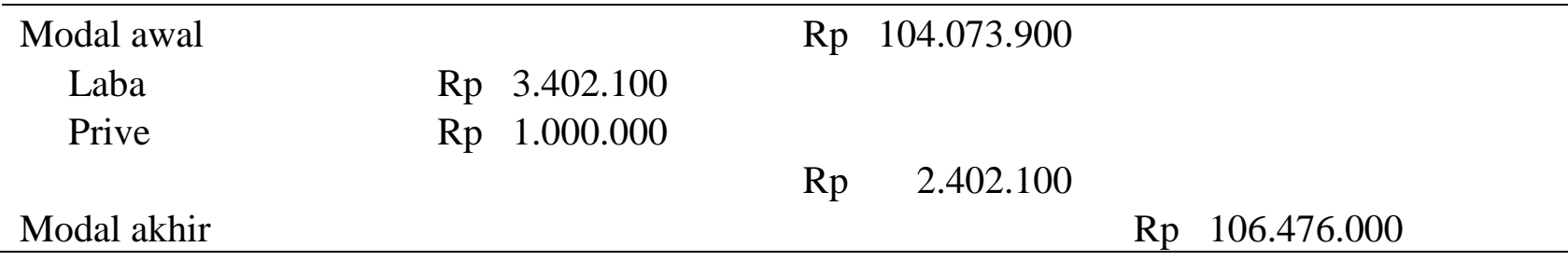

Sumber: CV. Citra Pandion Bernas

Tabel 3. Neraca CV Citra Pandion Bernas

CV Citra Pandion Bernas

Neraca

Desember 2012

\begin{tabular}{|c|c|c|c|c|}
\hline \multicolumn{3}{|l|}{ Aktiva } & \multicolumn{2}{|l|}{ Pasiva } \\
\hline Aktiva Lancar & & & $\begin{array}{l}\text { Utang jangka } \\
\text { panjang }\end{array}$ & \\
\hline & & $\mathrm{Rp}$ & Utang Bank & $\mathrm{Rp}$ \\
\hline Kas & & 136.329 .000 & BRI & $\begin{array}{l}98.460 .000 \\
\mathrm{Rp}\end{array}$ \\
\hline Aktiva tetap & & & Modal Akhir & 106.476 .000 \\
\hline $\begin{array}{l}\text { Peralatan } \\
\text { Penyusutan peralatan } \\
\text { toko }(1 \%)\end{array}$ & $\begin{array}{l}\mathrm{Rp} \\
69.300 .000 \\
\mathrm{Rp} \\
693.000\end{array}$ & & & \\
\hline
\end{tabular}




\begin{tabular}{llll}
\hline & $\mathrm{Rp}$ & & \\
& 68.607 .000 & & \\
\hline & $\mathrm{Rp}$ & & $\mathrm{Rp} \mathrm{204}$ \\
Total Aktiva & 204.936 .000 & Total Pasiva & 936.000 \\
\hline
\end{tabular}

\section{Sumber: CV. Citra Pandion Bernas}

Dari laporan laba rugi yang disajikan CV Citra Pandion Bernas diatas telihat ketidak sesuaian ditinjau berdasarkan SAK ETAP yaitu:

1. CV. Citra Pandion Bernas tidak memisahkan pendapatan di luar usaha yang diperolehnya dan hanya mengakui adanya akun pendapatan kedalam laporan keuangannya padahal pada saat melakukan wawancara terdapat pendapatan yang diperoleh $\mathrm{CV}$ Citra Pandion Bernas di luar usahanya.

2. Pada akun pembelian perlengkapan toko yang dikelompokkan dalam akun beban oleh CV Citra Pandion Bernas sebesar Rp 8.478.900. CV Citra Pandion Bernas mengakui seluruh pembelian perlengkapan kantor sebagai beban, padahal dari hasil wawancara yang sudah penulis lakukan pada akhir tahun desember 2012 masih terdapat sekitar $30 \%$ perlengkapan yang tersisa dan hanya $70 \%$ yang digunakan untuk aktivitas operasi CV Citra Pandion Bernas. Hal tersebut tentunya dapat mempengaruhi kuantitas dari laba yang diperoleh, bukan itu saja jumlah laba yang dimasukkan pada laporan laba rugi akan mempengaruhi nilai pada laporan perubahan modal dan total aktiva dan pasiva yang dimiliki oleh CV Citra Pandion Bernas. Jika akun pembelian peralatan yang digunakan oleh CV Citra Pandion Bernas untuk melakukan aktivitas operasi hanya $70 \%$ dari total peralatan yang dimiliki Rp 8.478 .900 maka hanya $\mathrm{Rp}$ 5.935.230 yang akan menjadi beban.

Seraca keseluruhan berdasarkan paparan diatas bahwa CV Citra Pandion Bernas telah menerapkan Laporan keuangan berdasarkan SAK ETAP namun tidak sepenuhnya, masih banyak unsur yang tidak terdapat dalam laporan keuangan yang disajikan pada CV Citra
Pandion Bernas seperti tidak disajikan laporan arus kas, catatan atas laporan keuangan dan lainnya.

Berdasarkan hasil wawancara dan observasi yang sudah penulis lakukan ditemukan kendala yang dialami oleh CV Citra Pandion Bernas dalam menerapkan laporan keuangan berdasarkan SAK ETAP, yaitu:

1. Adanya kesalahan perhitungan yang dilakukan oleh CV Citra Pandion Bernas dalam memasukkan jumlah beban pada laporan laba-rugi. CV Citra Pandion Bernas memasukkan seluruh perlengkapan yang digunakan dalam aktivitas operasi perusahaan baik itu yang terpakai maupun yang tidak terpakai sebagai beban. Seharusnya yang digunakan sebagai beban hanya perlengkapan yang telah digunakan untuk aktivitas operasi perusahaan.

2. Tidak adanya pembagian tugas yang jelas antar bidang karena pemilik sekaligus menjadi pengelola usaha. Pemilik mengelola usaha sendiri, sehingga waktu yang dimiliki difokuskan untuk mengerjakan dan mengembangkan usaha. Karyawan hanya diberikan wewenang untuk melayani pelanggan dan menyelesaikan pekerjaan.

3. Pemilik juga memiliki usaha lain untuk dikembangkan sehingga tidak terlalu fokus pada suatu bidang usaha.

4. Kurangnya sumber daya manusia yang memiliki kemampuan dalam menyusun laporan keuangan karena tidak didukung dengan latarbelakang pendidikan akuntansi.

Laporan Keuangan Berdasarkan Standar Akuntansi Keuangan Entitas Tanpa Akuntabilitas Publik (SAK ETAP)

Dari ketidak sesuaian penyajian laporan keuangan $\mathrm{CV}$ Citra Pandion 
Bernas, maka berikut ini akan disajikan

ETAP

laporan keuangan yang sesuai dengan SAK

Tabel 4. Laporan Laba Rugi CV Citra Pandion Bernas Berdasarkan SAK ETAP

CV Citra Pandion Bernas

Laporan Laba/Rugi

Per 31 Desember 2012

Pendapatan

Pendapatan jasa

Rp 15.789.000

Pendapatan di luar jasa

Rp 1.650 .000

Rp 17.439.000

Beban

Beban gaji

Rp 2.250.000

Beban sewa took

Rp 1.050 .000

Beban listrik, air, telepon

Rp 1.565.000

Beban penyusutan peralatan toko

Rp 693.000

Beban perlengkapan toko

Rp 5.935.230

Rp 11.493.230

Laba

Rp 5.945.770

Sumber: data yang telah diolah

Tabel 5. Laporan Perubahan Modal CV Citra Pandion Bernas Berdasarkan SAK ETAP

CV Citra Pandion Bernas

Laporan Perubahan Modal

Per 31 Desember 2012

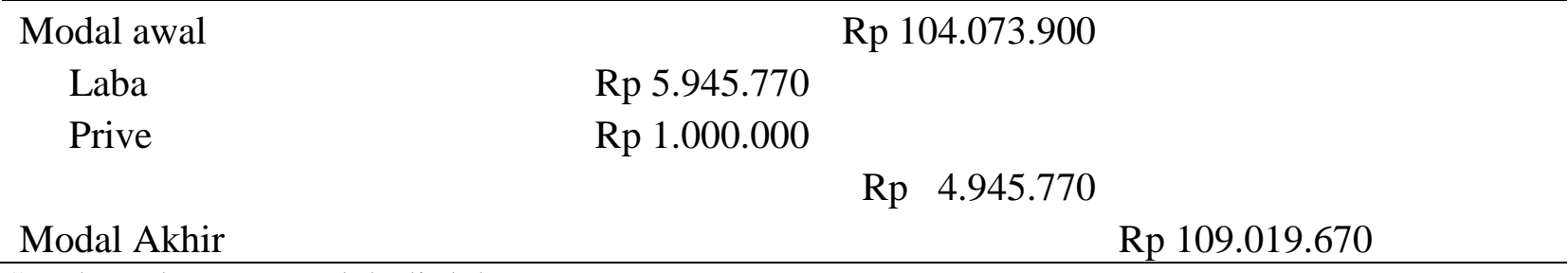

Sumber: data yang telah diolah

Dari penyajian laporan keuangan berdasarkan SAK ETAP terlihat bahwa terdapat perbedaan selisih laba yang diperoleh CV Citra Pandion Bernas sebesar Rp 2.543.670 hal tersebut dikarenakan CV Citra pandion bernas berasumsi bahwa pembelian seluruh perlengkapan dijadikan beban, padahal perlengkapan masih tersisa
$20 \%$ dari total perlengkapan periode desember 2012. Selisih tersebut juga akan mempengaruhi total dari modal akhir yang diperoleh yaitu sebesar $\mathrm{Rp} 2.543 .670$ dan akan perbengaruh juga terhadap perolehan aktiva dan pasiva pada neraca dengan selisih sebesar Rp 2.543.670.

Tabel 6. Neraca CV Citra Pandion Bernas Berdasarkan SAK ETAP

\section{Citra Pandion Bernas \\ Neraca \\ Per 31 Desember 2012}

\begin{tabular}{lc} 
Aktiva & Pasiva \\
\hline Aktiva Lancar & Utang jangka panjang \\
\hline
\end{tabular}




\begin{tabular}{|c|c|c|c|}
\hline \multirow[b]{2}{*}{ Kas } & & Utang Bank & \\
\hline & Rp 136.329.000 & BRI & Rp 98.460 .000 \\
\hline Perlengkapan toko & $\begin{array}{ll}\mathrm{Rp} & 2.543 .670 \\
& \operatorname{Rp} \\
138.872 .670\end{array}$ & Modal Akhir & Rp 109.019.670 \\
\hline \multicolumn{4}{|l|}{ Aktiva tetap } \\
\hline \multirow{3}{*}{$\begin{array}{l}\text { Peralatan kantor } \\
\text { Akumulasi penyusutan } \\
\text { peralatan toko }\end{array}$} & Rp 69.300.000 & & \\
\hline & 693.000 & & \\
\hline & Rp 68.607.000 & & \\
\hline & $\mathrm{Rp}$ & Total & $\mathrm{Rp}$ \\
\hline Total Aktiva & 207.479 .670 & Pasiva & 207.479 .670 \\
\hline
\end{tabular}

Sumber: data yang telah diolah

\section{KESIMPULAN}

Berdasarkan hasil penelitian ini, dapat ditarik kesimpulan bahwa penerapan laporan keuangan CV Citra Pandion Bernas ditinjau berdasarkan SAK ETAP belum sepenuhnya dilakukan. Masih terdapat beberapa unsur laporan keuangan yang tidak disajikan oleh CV Citra Pandion Bernas seperti laporan arus kas dan catatan atas laporan keuangan yang telah disyaratkan dalam SAK ETAP serta pembelian perlengkapan kantor yang dikelompokkan ke dalam akun beban seharusnya hanya jumlah perlengkapan yang digunakan dalam aktivitas operasi perusahaan atau terpakai saja yang dijadikan beban yaitu $70 \%$ dari jumlah perlengkapan.

Selain itu terdapat juga kendala yang dihadapi dalam menyusun laporan keuangan yaitu tidak adanya pembagian tugas yang jelas antar bidang karena pemilik sekaligus menjadi pengelola usaha. Kurangnya sumber daya manusia yang memiki kemampuan dalam menyusun laporan keuangan karena tidak di dukung dengan latarbelakang pendidikan akuntansi. Pemilik mengelola usaha sendiri, sehingga waktu yang dimiliki difokuskan untuk mengerjakan dan mengembangkan usaha. Karyawan hanya diberikan wewenang untuk melayani pelanggan dan menyelesaikan pekerjaan serta pemilik juga memiliki usaha lain untuk dikembangkan sehingga tidak terlalu fokus pada suatu bidang usaha.

\section{DAFTAR PUSTAKA}

$\underline{10.22202 / \text { economica.2013.v1.i2.123 }}$

Harahap, Sofyan Syafri. 2011. Teori Akuntansi. Jakarta: Rajawali Pers 2009. Analisis

Kritis Atas Laporan Keuanngan. Jakarta: Rajawali Pers

Soemarso S.R, 2004. Akuntansi Suatu Pengantar. Jakarta: Salemba Empat

Rudianto, 2009. Pengantar Akuntansi. Jakarta: Erlangga

Handoko, Yulian. 2004. Akuntansi. Jakarta: Bumi Aksara

Wirahardja, Roy Iman, dkk. 2010. Standar Akuntansi Keuangan UKM = SAK ETAP per 1 Januari 2011. Artikel. Jakarta

Ikatan Akuntan Indonesia. 2009. Standar Akuntansi Keuangan Entitas Tanpa Akuntabilitas Publik. Jakarta: Dewan Standar Akuntansi Keuangan.

Wulandari, Sartika. 2011. Penerapan Standar Akuntansi Keuangan 
Entitas Tanpa Akuntabilitas Publik (SAK ETAP) pada Usaha Mikro Kecil Menengah (Studi Kasus Di Kampung Batik Laweyan Surakarta. Jurnal. Surakarta

Aziz, Toha. 2013. Analisis Akuntansi Keuangan Koperasi Ditinjau Berdasarkan Standar

Akuntansi Keuangan Entitas Tanpa Akuntabilitas Publik (SAK ETAP). Jurnal. Madura

Putra, Hermon Adhy Putra. Kurniawati, Elisabeth Penti. Penyusunan Laporan keuangan untuk Usaha Kecil dan Menengah (UKM) Berbasis Standar Akuntansi Keuangan

Entitas Tanpa Akuntabilitas Publik (SAK ETAP). Jurnal. Universitas Kristen

Satya Wacana

Raflesia Nurdita JS. 2012. Analisis Penerapan Standar Akuntansi Keuangan Entitas Tanpa Akuntanbilitas Publik (SAK ETAP) pada Koperasi yang ada di Kota Dumai. Jurnal. Universitas Riau

Afifudin. Saebani, Beni Ahmad. 2012. Metodologi Penelitian Kualitatif. Bandung: CV. Pustaka Setia.

Sugiyono. 2012. Metode Penelitian Pendidikan. Bandung: Alfabeta

Robert K. Yin. 2002. Studi Kasus Desain dan Metode. Jakarta: Pt Raja Grafindo Persada. 